DOI https://doi.org/10.18551/rjoas.2020-11.03

\title{
STRATEGY DIRECTORATE GENERAL OF TAXES ON THE IMPLEMENTATION OF GOOD GOVERNANCE TO IMPROVE THE MOTIVATION AND TAXPAYERS COMPLIANCE
}

\author{
Astini Yuli*, Utama Made Suyana \\ Faculty of Economics and Business, University of Udayana, Bali, Indonesia \\ ${ }^{\star}$ E-mail: astini yul@yahoo.co.id
}

\begin{abstract}
The role of taxes is very vital to date in efforts to improve people's welfare. The decrease in the achievement of tax revenue deserves attention, especially during the Covid-19 pandemic. One of the strategies implemented by the Directorate General of Taxes is to increase taxpayer motivation and compliance through the implementation of good governance. This study is intended to explore the implementation of good governance conducted by the Directorate General of Taxes to increase motivation and taxpayer compliance by using secondary data and a descriptive approach. The results of the study conclude that the implementation of good governance is carried out by the Directorate General of Taxes by providing excellent public services; provide counseling, services, and effective public relations; conduct inspections and effective billing; conduct effective law enforcement; improve the quality of human resources, and maintain the reliability of the Information Management System.
\end{abstract}

\section{KEY WORDS}

Directorate general of taxes, good governance, motivation, taxpayer compliance.

The government always directs various development programs to improve people's welfare by reducing poverty, inequality, and unemployment. In achieving these development targets, the role of state revenue in the taxation sector is increasingly important and strategic in supporting the independence of state financing. This is due to the decreasing role of state revenue from the oil and gas sector. The Directorate General of Taxes as a government agency that carries out duties in the field of tax administration is tasked with securing the State Budget, especially in the tax revenue sector. The tax revenue achievements are shown in Table 1. The tax revenue target in the 2019 State Budget is 1,577.56 trillion rupiahs, tax revenue up to December 2019 reached 1332.06 trillion rupiahs, which is 84.44 percent of the target. The percentage of tax revenue achievement in 2019 decreased compared with the achievements of 2018 and 2017, ie respectively by 92.23 percent and 89.67 percent.

Table 1 - Tax Revenue Achievements in 2017-2019

\begin{tabular}{cccc}
\hline Year & Target & Realization & Achievement (Percent) \\
\hline 2017 & $1.283,57$ & $1.151,03$ & 89.67 \\
2018 & $1.424,00$ & $1.315,51$ & 92.23 \\
2019 & $1.577,56$ & 1332,06 & 84.44 \\
\hline
\end{tabular}

Source: Directorate General of Taxes, 2019.

Quoted from Financial Notes and draft budget presented to the parliament 2019, The International Monetary Fund (IMF) in the release of the World Economic Outlook shows that global economic growth in 2019 will be stagnant, accompanied by a slowdown in world trade volume. The weakening of global economic conditions, the lack of improvement in mining commodity prices and palm oil products, and a decrease in the volume of international trade transactions throughout 2019 under the shadow of a trade war and geopolitical conflict has resulted in a slowdown in national economic growth and put pressure on Indonesia's exportimport activities. Meanwhile, Indonesia's cumulative import value for the January-November 2019 period was USD 156.22 billion, or down 9.88 percent over the same period in 2018. 
This condition puts pressure on the tax revenue base, which causes the performance of tax revenue in 2019 to experience a slowdown (Directorate General of Taxes, 2019).

Based on Presidential Regulation Number 72 of 2020, tax revenues until August 2020 amounted to 676.9 trillion rupiahs or 56.5 percent of the target. Tax revenue until the end of August contracted 15.6 percent. Revenue from the manufacturing sector contracted by 16 percent, revenue from the trade sector contracted by 16.3 percent, the revenue from the financial services and insurance sector experienced a minus growth of 5.5 percent, revenue from the construction and real estate sector was minus 15.1 percent, revenue from the mining sector was minus 35.7 percent, and revenues from the transportation and warehouse sectors contracted by 10.4 percent. The main cause of the contraction in revenues was due to Large-Scale Social Restrictions during the Covid-19 pandemic. Also, the use of the Covid19 fiscal incentives starting April will add to tax revenue pressure.

One of the reasons for not achieving the tax revenue target is the lower level of taxpayer compliance. Kirchler, Hoelzl, \& Wahl (2008) state that taxpayer compliance in carrying out their tax obligations can be divided based on their motivation, namely taxpayers carry out tax obligations because they are aware of the tax function and are aware of their obligations as citizens (voluntary compliance) and taxpayers carry out tax obligations because it takes into account that the cost consequences of non-compliance are very high (enforced compliance). Formal tax compliance includes compliance with the submission of annual tax returns of Income Tax, both corporate taxpayers and non-employee individual taxpayers. The amount of the taxpayer is registered per December 31, 2019, amounted to 41,996,743. Meanwhile, the number of annual tax returns of Income Tax 1770 and 1771 which is submitted by the taxpayer is $3,257,567$ annual tax returns out of $4,514,765$ total corporate taxpayers and non-employee individual taxpayers who are subject to annual tax returns or reaching 72.52 percent. Of the 4,514,765 total corporate taxpayers and nonemployee individual taxpayers who are obliged to pay annual tax returns, who made payments were 2,305,558 taxpayers.

Taxpayer compliance can be improved by increasing taxpayer motivation. Luttmer \& Singhal (2014) considers tax morale as a series of motivations that underlie tax compliance through five mechanisms such as (1) intrinsic motivation, namely personal satisfaction such as pride when being a taxpayer is obedient or vice versa feeling ashamed and guilty if not obeying, (2) reciprocal relationships between citizens and government, such as willingness to pay taxes and the availability of public services, (3) the influence of friends and society, namely peer compliance can provide a positive signal in tax-paying behavior, (4) cultural factors or social norms, namely values that have been embedded in an environment across generations, and (5) imperfect information received by taxpayers, for example regarding the possibility of a tax audit. According to Dwenger, Kleven, Rasul, \& Rincke (2016), the form of taxpayer motivation is in the form of extrinsic and intrinsic motivation. Extrinsic motivation is related to tax prevention and policy, whereas intrinsic motivation such as morals, guilt, reciprocity, and social norms.

Taxpayer's compliance and motivation can be enhanced by the implementation of good governance. Sebele-Mpofu (2020) found a significant relationship between the quality of governance, tax morale, and tax compliance. The higher the quality of public governance and services provided by the government, the higher the level of tax morale and tax compliance (Alasfour, Samy, \& Bampton, 2016; Vythelingum, Soondram, \& Jugurnath, 2017). Public services are a strategic point for implementing good governance because: 1) Public services have been the domain where the state represented by the government interacts with non-governmental organizations. Success in public services will encourage high public support for bureaucratic work; 2) Public service is a realm where various aspects of clean and good governance can be articulated easily; and 3) Public services involve the interests of all elements of governance, namely government, society, and market mechanisms (Maryam, 2016). In line with Kiow, Salleh, \& Kassim (2017) that the compliance behavior of individual taxpayers is influenced by transparency by the government. Taxpayers pay attention to the transparency of information provided by the government, especially in public procurement. If the government uses taxes wisely, it will motivate compliance and also 
lead to increased compliance when taxpayers benefit from taxes paid in the form of public goods and social facilities.

The implementation of good governance can encourage taxpayer compliance. Achieving these goals requires a high commitment from tax officials to implement the principles of good governance optimally and sustainably which include transparency, accountability, responsibility, independence, and fairness (Panjaitan, Tarmizi, Daulay, \& Ginting, 2019). Ayuba, Puteri, \& Safinaz (2016), Shahzad \& Khan (2018) found a positive and significant relationship between the quality of public governance and tax compliance. This study aims to describe how the implementation of good governance carried out by the Directorate General of Taxes is one of the strategies used in efforts to increase taxpayer motivation and compliance. This study uses secondary data and a descriptive approach.

\section{RESULTS OF STUDY}

The implementation of good governance is one of the strategies used by the government (Directorate General of Taxes) to increase taxpayer motivation and compliance. The elaboration of this strategy is outlined in the Decree of the Director-General of Taxes Number KEP-95 / PJ / 2015 concerning the Strategic Plan of the Directorate General of Taxes 2015-2019 which is described as follows.

Implementation of good governance through excellent public services. Improving the quality and improving the image of public services are the ultimate goals of the Ministry of Finance's Bureaucratic Reform. With the achievement of these main objectives, it is hoped that the level of service satisfaction to the community as service users or stakeholders will be better. At least, the expectations of the parties being served are fulfilled with the services provided that are better or even provide added value. To meet the satisfaction of service users or stakeholders and in line with the implementation of Legislation Number 25 of 2009 concerning Public Services, then the provision of services must be based on public interest, legal certainty, equal rights, the balance of rights and obligations, professionalism, participation, equality of treatment, openness, accountability, facilities and special treatment for vulnerable groups, timeliness and speed, convenience, and affordability.

There are eleven service aspects according to Legislation Number 25 of 2009 concerning Public Services namely: (1) Openness or easy access to information; (2) Service information; (3) The conformity of the procedure with the stipulated provisions; (4) Attitudes of employees; (5) Ability of employee skills; (6) Supporting environment; (7) Access to service offices; (8) Service completion time; (9) Payment of fees according to established rules/conditions; (10) Imposing sanctions/fines for violations of the terms of service; and (11) Environmental and service safety. The results of the 9 (nine) aspects of Directorate General of Taxes service user satisfaction in 2018 and 2019 are shown in Table 2 which describes the Directorate General of Taxes service user satisfaction index in 2019 reaching a score above 4 (good) from a measurement scale of 1 (one) to 5 (five) which means it has met the satisfaction of service users. Service aspects that have the best performance are environmental and service safety at 4.59; Employee attitude of 4.53; Supporting environment 4.49 and conformity of procedures with the stipulated provisions of 4.48 .

Table 2 - User Satisfaction Survey Results Service Directorate General of Taxes 2018 and 2019

\begin{tabular}{lllll}
\hline Number & Aspects of Service & 2018 & 2019 & Deviation \\
\hline 1 & Openness or easy access to information & 4.26 & 4.33 & 0.07 \\
2 & Service information & 4.31 & 4.40 & 0.09 \\
3 & The conformity of the procedure with the stipulated provisions & 4.34 & 4.48 & 0.14 \\
4 & Attitudes of employees & 4.38 & 4.53 & 0.15 \\
5 & The ability of employee skills & 4.27 & 4.40 & 0.13 \\
6 & Supporting environment & 4.34 & 4.49 & 0.15 \\
7 & Access to service offices & 4.33 & 4.47 & 0.14 \\
8 & Service completion time & 4.22 & 4.37 & 0.15 \\
9 & Environmental and service safety & 4.41 & 4.59 & 0.18 \\
\hline
\end{tabular}

Source: Directorate General of Taxes, 2019. 
According to Khaerunnisa \& Wiratno (2014), the service aspect is openness or easy access to information as a form of transparency, which is a principle that guarantees access or freedom for everyone to obtain information about governance, namely information about policies, the process of making and implementing them, and the results achieved. This principle has two aspects, namely public communication by the government and the public's right to access information. Both will be very difficult to do if the government does not handle its performance properly. Good performance management is the starting point of transparency.

The role of the media is also very important for government transparency, both as an opportunity to communicate to the public and explain various relevant information, as well as a "watchdog" for various government actions and deviant behavior from bureaucratic officials. The media will not be able to do this task without freedom of the press, free from government intervention, or the influence of business interests. Openness has the consequence of excessive control from the public and even by the mass media. Therefore, the obligation to disclose must be balanced with the value of restrictions, which include clear criteria from public officials about what types of information they provide and to whom the information is given. The principle of transparency can be measured through several indicators such as: ensure an open system and standardization of all public service processes, facilitate public inquiries about various public policies and services, as well as processes in the public sector, facilitate reporting and dissemination of information as well as misconduct by public officials in serving activities.

According to Syakura \& Baridwan (2014), tax authorities can increase taxpayer trust by implementing a clean government system and excellent service. This result is in line with the deterrence theory that a person's behavior is influenced by the paradigm of benefits, costs, and risks of each action to be chosen. This theory analogizes that taxpayer compliance in paying taxes is influenced by the taxpayer's perception of public services, fair tax policies, and the development that taxpayers get when paying taxes. Therefore, the tax authorities are expected to provide good public services, good development, and fair policies to increase taxpayer confidence so that it can indirectly improve taxpayer compliance in fulfilling tax obligations. The results of this study can also be linked to agency theory that in the application of the self-assessment system, there is a delegation of unequal information ownership relations between the tax authority (principal) and the taxpayer (agent). The existence of this information asymmetry can motivate taxpayers to commit tax evasion by violating applicable tax regulations. Moreover, the disclosure of cases of corruption and embezzlement of tax money by tax authorities has further reduced taxpayer confidence and indirectly decreased taxpayer compliance in paying taxes.

The results of research by Tahar \& Sandy (2016) show that the taxpayer's perception of the service of the Tax Office has a significant effect on taxpayer compliance. If the better the quality of service provided by tax officers to taxpayers, it will motivate taxpayers to pay taxes. Damayanti \& Martono (2018) trust taxpayers in the tax system direct them to comply with tax regulations. The importance of trust in influencing tax compliance does not only refer to the trust of business owners in the tax authorities but also the perception of taxpayers who are trusted by tax authorities in fulfilling their tax obligations. Sukesi \& Yunaidah (2020) found that service quality directly has a significant effect on taxpayer compliance. Service quality can be measured by indicators based on the Regulation of the Minister of State Apparatus Reform Number 14 of 2017 concerning Guidelines for Preparing Community Satisfaction Surveys for Public Service Provider Units which include elements of Requirements; Systems, Mechanisms, and Procedures; Completion Time; Fees / Rates; Product Specifications Type of Service; Implementing Competencies; Implementing Behavior; Handling of Complaints, Suggestions and Inputs; as well as facilities and infrastructure.

Implementation of good governance through the effectiveness of counseling, services, and public relations. Counseling about tax rights and obligations as well as positive news and information regarding taxation can foster an understanding of taxpayers on tax issues. Extension activities are an effort and process of providing tax information to produce changes in the knowledge, skills, and attitudes of the community, business world, 
government, and non-government agencies and institutions so that they are motivated to understand, be aware, care, and contribute in carrying out tax obligations by applicable regulations. The focus of the counseling is prospective future taxpayers, potential taxpayers, new taxpayers, and registered taxpayers. Extension activities are divided into two types, namely: 1) The socialization activities or the provision of tax information to the public and the taxpayer/power of the taxpayer, such as a) socialization of regulation/taxation policies; b) socialization of tax awareness; and c) socialization at the request of other parties. 2) The extension accounted for contributing to behavioral change that is done is segmented among others to a) the taxpayer non-registrant; b) new taxpayers; c) taxpayers pay no report; d) registered taxpayers do not report any data, and e) certain taxpayers to increase compliance.

The extension is carried out to provide socialization and education regarding taxation, both the rights and obligations of taxpayers. However, the taxpayers' lack of knowledge and skills in taxation is a challenge for all tax officials to increase the quantity and quality of counseling so that the level of understanding of taxpayers is getting better. In the Year 2017, the Directorate General of Taxes has a large database of taxation as a basis for the extension target behavior change goals with a target of 55 percent. The tax amnesty program also adds to the taxation database. So that realization in 2017 was 83.03 percent. Then in 2018, the target has increased to 60 percent while the taxation database has not increased much so that the realization in 2018 has decreased to 81.87 percent. In 2019, the target has increased to 65 percent and the Directorate General of Taxes has begun to prepare a compliance map through the Compliance Risk Management (CRM) Extension which can be used as material for a list of extension targets, so that the realization will increase to 84.74 percent.

Providing services by established standards and procedures, resulting in service outputs that can be utilized by customers, and according to the needs of taxpayers. The number of tax service complaints that are followed up on time is the number of complaints related to taxation services, as regulated in the Regulation of the Director-General of Taxes which regulates the Procedure for Submitting Tax Service Complaints which has been inputted into the Tax Complaint Information System and has closed status at the end of the period. Realization of Percentage of Complaints Follow-Up on Timely Taxation Services in 2019 reached 100 from the target of 85 so that the achievement is 117.65 percent. The percentage of Complaints Follow-up on Tax Service on Time of 117.65 percent above indicates that the Director-General of Taxes is very concerned about public/taxpayer complaints and is responsive in following up on these complaints.

Effective public relations is the implementation of public relations activities including the delivery of tax information to the public in the framework of building the reputation of the Directorate General of Taxes and supporting efforts to increase taxpayer compliance. The level of public relations effectiveness in 2019 reached 85.82 from the target of 80 percent so that the percentage achievement is 107.28 percent. The level of effectiveness of public relations is formed from three aspects, including awareness of advertising/news, awareness of advertising/news themes, and understanding of advertising/news themes. With a weighted proportion, advertising/news awareness is 40 percent, advertising/news theme awareness is 30 percent, and understanding advertising/news theme is 30 percent. Of the three aspects, the advertising/news awareness aspect had the highest percentage, namely 100 , then the understanding aspect of the advertising/news theme was 82.25 , and the lowest aspect was the advertising/news theme awareness at 70.47. The achievement of the level of effectiveness in public relations of 85.82 shows that the message conveyed by the Directorate General of Taxes through the public relations media is increasingly understood and considered effective by the public. The Public Relations Effectiveness Level in 2019 was 85.82, a significant increase compared to the previous year, which was 3.95 points. This is because the information media that is often consumed by the public is television at 81.65 percent and social media at 71.06 percent. This shows that the publication of tax information through communication media is by the information media consumed by the public.

The results of research by Sukesi \& Yunaidah (2020), the effectiveness of taxation socialization through television, radio, print media (newspapers, banners \& brochures), and 
tax consultations can lead to taxpayer satisfaction in gaining more knowledge about the importance of tax payments. The existence of superior service innovations and perfect quality infrastructure and effective services will spoil taxpayers. By doing this, taxpayers find it helpful, and therefore they can improve compliance to pay taxes on time and according to the income received. Herryanto \& Toly (2013) found that tax socialization activities had not had a significant impact on income tax revenue because the socialization activities carried out were not optimal, and have not succeeded in meeting the target and most of the taxpayers take part in taxation socialization activities only as a compulsion, but still do not comply with their obligations. Cyan, Koumpias, \& Martinez-Vazquez (2016) suggest optimizing the tax authority's communication strategy by increasing the target taxpayer choice.

Socialization activities or tax extension can be made directly and indirectly. Direct socialization is a tax socialization activity by directly interacting with taxpayers or prospective taxpayers. Forms of direct socialization that have been held include Early Tax Education, Tax Goes To School/Tax Goes To Campus, tax competitions (Quiz, Debates, Tax Speeches, Articles), workshop/tax gatherings, tax classes/tax clinics, seminars/discussions/lectures, and workshops/technical guidance. Indirect socialization is an activity to socialize taxation to the public with little or no interaction with participants. Examples of indirect socialization activities include socialization via radio/television, distribution of tax books/booklets/leaflets. The forms of indirect socialization can be distinguished based on the medium. With electronic media, this can be in the form of TV talk shows, built-in programs, and radio talk shows. Meanwhile, the printed media (newspapers/magazines/tabloids/books) can be in the form of supplements, advertorials (tax booklets/leaflets), question and answer rubrics, writing tax articles, and publication of magazines/books/education props (including tax comics).

Implementation of good governance through the effectiveness of audits and billing. Examining taxpayers is one of the roles and duties of the tax authorities with the implementation of a self-assessment system in Indonesia. The definition of examination according to article 1 paragraph (25) of Legislation Number 28 of 2007 is a series of activities to collect and process data, information, and/or evidence which are carried out objectively and professionally based on an inspection standard to test compliance with taxation obligations and/or for other purposes in the framework of implementing the provisions of tax laws and regulations. Minister of Finance Regulation Number 82/PMK.03/2011 concerning Tax Audit Procedures, an audit to test the compliance of the Taxpayer's tax obligations must be carried out if the Taxpayer applies for a refund of the excess (restitution) of tax payments (article 3 paragraph 2) and it can be done if the Taxpayer: 1) submit an annual tax return stating overpayment, including those that have been given a preliminary refund of the excess tax; 2) submitting an annual tax return stating loss; 3) does not submit or deliver the annual Tax Return but it exceeds the period stipulated in the Warning Letter; 4) carry out merger, consolidation, expansion, liquidation, dissolution, or will leave Indonesia forever; and 5) submitting an annual Tax Return that meets the selection criteria based on the results of risk analysis indicating that the Taxpayer's tax obligations are not fulfilled by the provisions of the taxation legislation.

Apart from testing taxpayer compliance, Article 30 paragraph 2 also states that audits can be carried out for other purposes. Examination for other purposes in implementing the provisions of the taxation legislation and regulations is carried out with the following criteria: 1) giving ex officio Taxpayer Identification Number; 2) deletion of Taxpayer Identification Number; 3) affirmation or revocation of the taxable entrepreneur; 4) Taxpayers file an objection; 5) collection of materials for the preparation of Net Income Calculation Norms; 6) matching data and/or information tools; 7) determination of taxpayers to be located in remote areas; 8) determination of one or more places where Value Added Tax is payable; 9) examination in the framework of tax collection; 10) determining when production starts or extending the period of compensation for losses in connection with the award.

The audit is the implementation of the supervisory function on compliance with tax obligations by the prevailing legislations and regulations. The percentage of Audit Completion aims to increase stakeholder confidence and taxpayer compliance to support 
state revenue through the effectiveness of audit activities that can cause a deterrent effect. Conversion Examination Completion Target (Conversion Target) is a 34,128 Conversion Report of audit findings nationally. For this target, in 2019 the completion of the inspection of 115.96 percent of the target can be achieved with details of 58,967 Completed Report of audit findings (Real Report of audit findings), 39,737 Report of audit findings completed on time, 19,230 Report of audit findings not on time in total conversion of 39,580 Conversion Report of audit findings. A conversion is a unit of measurement for examination completion by calculating scoring based on the timeliness of examination completion.

Percentage of Tax Receivable Disbursement is a performance indicator for measuring tax receipts through the disbursement of tax receivables based on the percentage of outstanding receivables balance through collection actions as regulated in the Tax Collection Legislation with Force Letter Number 19 of 2000. The percentage of tax receivables disbursement aims to increase stakeholder confidence and taxpayer compliance to support optimal revenue levels through increased disbursement of tax receivables. The achievement of tax receivable disbursement from 2017 to 2018 has decreased from 187.95 percent in 2017 to 156.61 percent in 2018. Meanwhile, the achievement of accounts receivable disbursement decreased from 156.61 percent in 2018 to 126.45 percent in 2019. The achievement of tax receivables disbursement that occurred during the period 2017 to 2019 shows that the achievements of the Tax Bailiff's performance through the collection actions that have been implemented are as expected. Collection actions that have been carried out are expected to provide a deterrent effect for taxpayers to be more compliant in carrying out their tax obligations.

In line with the results of research by Herryanto \& Toly (2013) that tax audits have a significant effect on income tax revenues. According to Utami \& Susyanti (2018), the perception of the possibility to be audited can increase taxpayer compliance. If taxpayers have a fear of being examined or audited, they tend to be more compliant. Cyan, Koumpias, \& Martinez-Vazquez (2016) found that taxpayers with relatively higher or lower tax morale do not directly increase voluntary tax compliance. So it is necessary to improve tax administration with more cost-effective tax enforcement.

Implementation of good governance through the effectiveness of law enforcement. As stated in the Strategic Plan of the Directorate General of Taxes 2015-2019, the Directorate of Law Enforcement plays an important role in formulating and implementing policies and technical standardization in the field of tax law enforcement with the ultimate goal of providing a deterrent effect on the principle of justice for taxpayers who avoid taxes, especially for taxpayers who are indicated to have committed criminal activities in the field of taxation through efforts law enforcement. One of the important activities carried out by the Directorate General of Taxes is the process of investigating taxpayers who are indicated to have committed taxation crimes, aiming to increase law enforcement efforts through effective investigations of tax crime cases to provide a deterrent effect for taxpayers, so that tax regulations can be adhered to in voluntary compliance.

For 3 (three) years from 2017 to 2019, the results of the investigation that have been declared complete by the judiciary (P-21) have exceeded the predetermined target. The percentage of investigation results that have been declared complete by the judiciary (P-21) in 2017 was 115.52 percent, in 2018 it was 107.63 percent, and in 2019 it was 107.46 percent. The P-21 target for both the Regional Office and the Directorate of Law Enforcement is determined annually by the Directorate of Law Enforcement. Although the percentage of achievement of P-21 achievement decreased in 2017 when compared to 2018 , in terms of quantity, production or the amount of achievement of P-21 increased every year, so it can be said, the achievement of P-21 every year shows an increasing trend even though the percentage shows a downward trend.

The results of research by Syakura \& Baridwan (2014) show that the fairer tax system in Indonesia will increase taxpayer compliance in paying taxes. The existence of fairness in the application of tax sanctions and the possibility of a tax audit can increase taxpayer compliance. Taxpayers will avoid tax evasion because this behavior is unethical and has a high risk if it is known by tax officials. Heavy tax sanctions will have a deterrent effect on tax 
violators so that taxpayers will prevent this from happening by complying with applicable tax regulations.

Tax sanctions can affect taxpayer compliance from two perspectives. The first perspective is an instrumental perspective, which states that it is sometimes advantageous to not comply with tax regulations if the sanctions imposed for such violations are less than the benefits derived from committing an offense. Thus the instrumental perspective emphasizes that the level of sanctions must be greater than the benefits derived from committing violations. The second perspective is a relational perspective which states that deterrence only variables (such as fines and tax audits) are not sufficient to explain the sanction system. The perspective is based more on concepts such as procedural justice, trustworthiness, and evaluation of tax authority morale to explain why tax sanctions can increase compliance. Higher levels of sanctions that can improve compliance only if sanctioned by the authority granting procedure are deemed reasonable and fair ((Ratmono, 2014). Alasfour et al. (2016); Cevik (2016) found that increasing the perception of fairness and equality in the tax system will improve tax morale and compliance.

The implementation of good governance through the availability of competent human resources. Excellent performance employees are employees of the Directorate General of Taxes who have high standards of professionalism with the indicators being all employees who meet the competency standards of the position, employees who have high attachment and pride to the organization, and employees who have high integrity. By having highperforming employees, it is hoped that organizational goals can be achieved. To determine the suitability of an official's competence with the competency standards required in a position, a competency assessment is carried out in the form of an Assessment Center using a multi assessor and multi-tools. By the Minister of Finance Regulation Number 219/PMK.01/2017 concerning Managerial Competency Assessment through Assessment Center in the Ministry of Finance, Position Competency Standards are a list of names and competency levels required in a position according to predetermined criteria.

The percentage of officials who have met job competency standards aims to improve the employee placement system based on competency and the availability of competent officials according to their positions to support the realization of performance and competency-based human resource management systems. The measurement of this indicator is by comparing the number of employees who have Job Person Match $=74$ percent with the number of employees who have been assessed. Job Person Match is the conformity between the competency level obtained from the Assessment Center with the Position Competency Standard. Position Competency Standards are the requirements for behavior, knowledge, and skills that must be in a position to ensure that the job duties can be carried out properly. In 2019, the number of echelons II, III, and IV officials were 5,191. Of these, 4,870 employees participated in the Assessment, with a Job Person Match greater than or equal to 74 percent as many as 4,625. Meanwhile, 241 employees who have Job Person Match less than 74 percent and 321 officials who have not had an Assessment Center.

According to Khaerunnisa \& Wiratno (2014), the quality of human resources can be observed from the professional ability by the field of duty that is their responsibility. Several factors that can affect human resources include the level of education, training, and placement of employees in positions. In carrying out duties, the principles contained in good governance are a reference for the implementation of a government that can synergize with the community, in the framework of optimal implementation of public services, the attitude of government officials who commit irregularities in the implementation of government administration and management can lead to development results and most of the public services are not as expected and planned. Therefore, the existence of a qualified apparatus will largely be determined by the ability of the apparatus concerned to implement the principles of good governance in the delivery of public services. Ali \& Nasaruddin (2020) found that taxpayers have the willingness to pay taxes because they are supported by Account Representative services or tax officers who have a broad understanding and insight into services so that taxpayers have the drive and motivation to fulfill their tax obligations. 
Implementation of good governance through the reliability of the Information Management System. A reliable Management Information System will be realized by the existence of reliable management of information and communication technology (ICT) services, namely by providing and fulfilling ICT services, as well as resolving ICT service interruptions to ICT service users according to the agreed terms in the ICT Service Catalog, Service Level Agreement, and Business Impact Analysis. The level of ICT system downtime is the interruption of the Ministry of Finance's ICT services to external users/stakeholders who have a very high level of criticality due to disruption/cessation of ICT service infrastructure which includes: Electricity, internet, intranet, Server/Operating System, Applications, and/or Database. ICT services with a very high level of criticality are determined based on the impact on the operational continuity of the organization and by considering the following factors: a). Potential financial losses; b). Potential lawsuits; c). Ministry of Finance image; and d). Several users were harmed.

The ICT system downtime rate target in 2019 has changed from 2018 which was originally 0.35 percent to 0.10 percent. Data polarization is determined to use minimize, where the less unplanned downtime, the lower the downtime realization so it is expected that ICT services to external users/stakeholders who have a very high level of criticality will be better. The ICT system downtime rate is reported monthly to the Center for Information Systems and Financial Technology using the provided working paper files. The ICT services used as the basis for the calculation are e-Filing, e-Billing, e-Bupot, e-Registration, e-Faktur; and www.pajak.go.id site. The realization until 2019 is 0.0031 percent of the ICT system downtime with a target of 0.10 percent so that the achievement is 196.9 (maximum achievement of 120). Of the 6 applications measured in 2019, only the www.pajak.go.id site experienced unplanned downtime in March 2019. Other applications such as e-Filing, eBilling, e-Bupot, e-Registration, and e-Faktur did not experience unplanned downtime. Except for the user's office network, downtime occurred due to the disruption of the user's network in August 2019.

According to Khaerunnisa \& Wiratno (2014), Information technology is used to support the government in taxation activities, both from a service perspective to an increase in the pace of development, which is one of the drivers of the goal of good governance. So that cooperation networks can be built based on participatory, transparent, and responsive relationships between the pillars of good governance. The use of information technology by the government, which allows the government to transform relations with the community, the business world, and other interested parties, can help the government and the provision of public services to be better and oriented towards community services. Conceptually, this information technology creates friendly and inexpensive interactions between the government and the community, because in practice information technology is a facility and communication for efficient and inexpensive government implementation, by improving public services by providing public facilities so that it is easy to get information, and creating good governance and the realization of a government that is more responsible for its citizens. With this information technology, a better government will be created, because the service process is more transparent, there is stronger public control, and time-stick monitoring, reduced corrupt practices because computers do not have the inherent nature of corrupt behavior.

Setiawan, Kurniawan, \& Payamta (2018) that the perception of taxpayers on the use of the e-filling system is very important to increase the level of taxpayer compliance. The application of information technology in taxation in Indonesia to simplify, optimize, and improving services to the public, especially taxpayers. The Directorate General of Taxes carries out a gradual renewal with a focus on public service and supervision of the fulfillment of tax obligations. Updates in the field of taxation are carried out with the use of electronic means via the internet, starting with registration as a taxpayer (e-registration), tax payment (e-transaction and e-payment), and tax reporting with an e-filling. Madni, Chaudhary, \& Ahmad (2020) also concluded that the simplification of the tax system and the adoption of modern information technology can increase tax morale. According to Irefe-esema \& Akinmade (2020), the effectiveness of tax automation procedures can reduce embezzlement 
and corrupt practices due to the elimination of direct physical contact between tax officers and taxpayers. Tax automation can improve registration and payment compliance, but not filing and reporting compliance due to the complexity of the electronic platform.

\section{CONCLUSION}

Based on the discussion previously described, it can be concluded that the strategy used by the government, in this case, is the Directorate General of Taxes to increase taxpayer motivation and compliance through the implementation of good governance with 1) Providing excellent public services by implementing service aspects in Legislation Number 25 of 2009 concerning Public Services, can increase satisfaction for service users (taxpayers), thereby motivating taxpayers to comply with applicable tax regulations; 2) Providing effective counseling, services, and public relations by providing socialization and education regarding taxation, to increase the taxpayer's tax knowledge and skills. With a better level of understanding of the taxpayer, it can motivate taxpayers to pay taxes by the provisions; 3) Performing an effective inspection and collection which creates a deterrent effect as a form of monitoring on compliance with tax obligations by the prevailing legislations and regulations. With the completion of an effective inspection and collection, it can increase stakeholder confidence and taxpayer compliance; 4) Conducting effective law enforcement that can provide a deterrent effect with the principle of justice for Taxpayers who avoid taxes, especially for Taxpayers who are indicated to have committed criminal activities in the field of taxation to increase motivation and compliance of taxpayers; 5) Improve the quality of human resources by providing officials with competence according to their positions to ensure that tasks can be carried out properly, and in the context of optimal implementation of public services to increase motivation and taxpayer compliance; and 6) Maintaining the reliability of the Information Management System to simplify, optimize, and improve services to taxpayers so that cooperation networks can be built based on participatory, transparent and responsive relationships between the pillars of good governance. A reliable Information Management System can motivate taxpayers to pay taxes by applicable regulations.

Based on the conclusion, it is recommended that the Directorate General of Taxes continue to improve services to the public, especially in the aspects of easy access to information and service completion time. Increasing the quantity and quality of counseling is also important to do with direct interaction so that the level of understanding of taxpayers is getting better. The placement of officials who are competent according to their positions needs more attention so that taxpayers have better confidence. As well as updating the information system that makes it easier for taxpayers to exercise their rights and obligations.

\section{REFERENCES}

1. Alasfour, F., Samy, M., \& Bampton, R. (2016). The determinants of tax morale and tax compliance: Evidence from Jordan. In Advances in Taxation (Vol. 23). https://doi.org/10.1108/S1058-749720160000023005.

2. Ali, I., \& Nasaruddin, F. (2020). Several factors influence the willingness to Pay taxes. Point of View Research Accounting and Auditing, 1(3), 57-70. https://doi.org/10.47090/povraa.v1i3.41.

3. Ayuba, A., Puteri, T., \& Safinaz, I. (2016). Factors, psychological factors and tax compliance: Evidence from nigerian SMEs. Malaysian Management Journal, 20(December), 41-57.

4. Cevik, S. (2016). Tax Morale and Tax Compliance in Socio-Political Context. International Journal of Politics \& Economics, (November).

5. Cyan, M. R., Koumpias, A. M., \& Martinez-Vazquez, J. (2016). The determinants of tax morale in Pakistan. Journal of Asian Economics, 47, 23-34. https://doi.org/10.1016/j.asieco.2016.09.002.

6. Damayanti, T. W., \& Martono, S. (2018). Taxpayer Compliance, Trust, and Power. Jurnal Keuangan Dan Perbankan, 22(2), 231-239. https://doi.org/10.26905/jkdp.v22i2.1580. 
7. Dwenger, N., Kleven, H., Rasul, I., \& Rincke, J. (2016). Extrinsic and intrinsic motivations for tax compliance: Evidence from a field experiment in Germany. American Economic Journal: Economic Policy, 8(3), 203-232. https://doi.org/10.1257/pol.20150083.

8. Herryanto, M., \& Toly, A. A. (2013). Pengaruh kesadaran wajib pajak, kegiatan sosialisasi perpajakan, dan pemeriksaan pajak terhadap penerimaan pajak penghasilan di KPP Pratama Surabaya Sawahan (The influence of taxpayer awareness, tax socialization activities, and tax audits on income tax revenues at the Surabaya Sawahan Primary Tax Office). Tax and Accounting Review, 1(1), 124-135.

9. Irefe-esema, J., \& Akinmade, B. (2020). Automation and Tax Compliance: Empirical Evidence from Nigeria. American Journal of Theoretical and Applied Business.

10. Kementerian Keuangan Republik Indonesia. (2019). Laporan Kinerja Direktorat Jenderal Pajak Tahun 2019.

11. Keputusan Menteri Pendayagunaan Aparatur Negara No.63/KEP/M.PAN/7/2003 tentang Pedoman Umum Penyelenggaraan Pelayanan Publik.

12. Keputusan Direktur Jenderal Pajak Nomor KEP-95/PJ/2015 tentang Rencana Strategis Direktorat Jenderal Pajak Tahun 2015-2019.

13. Khaerunnisa, I., \& Wiratno, A. (2014). Pengaruh moralitas pajak , budaya pajak , dan good governance terhadap kepatuhan wajib pajak (The influence of tax morality, tax culture, and good governance on taxpayer compliance). Jurnal Riset Akuntansi Dan Perpajakan, 1(2), 211-224.

14. Kiow, T. S., Salleh, M. F. M., \& Kassim, A. A. B. M. (2017). The Determinants of Individual Taxpayers' Tax Compliance Behaviour in Peninsular Malaysia. International Business and Accounting Research Journal, 1(1), 26. https://doi.org/10.15294/ibarj.v1i1.4

15. Kirchler, E., Hoelzl, E., \& Wahl, I. (2008). Enforced versus voluntary tax compliance: The "slippery slope" framework. Journal of Economic Psychology, 29(2), 210-225. https://doi.org/10.1016/j.joep.2007.05.004.

16. Luttmer, E. F. P., \& Singhal, M. (2014). Tax morale. Journal of Economic Perspectives, 28(4), 149-168. https://doi.org/10.1257/jep.28.4.149.

17. Madni, G. R., Chaudhary, M. A., \& Ahmad, N. (2020). Institutional Determinants of Tax Morale in Pakistan. Forman Journal of Economic Studies, 15, 209-255. https://doi.org/10.32368/fjes.20191509.

18. Maryam, N. S. (2016). Mewujudkan Good Governance Melalui Pelayanan Publik (Realizing Good Governance Through Public Services). Jurnal IImu Politik Dan Komunikasi, $\mathrm{VI}(1), 1-18$.

19. Panjaitan, H., Tarmizi, H. B., Daulay, M., \& Ginting, R. (2019). Effect of Good Governance, Tax Understanding, and Tax Sanctions on Taxpayers Compliance, Micro, Small and Medium Enterprises In Medan. International Conference of Organizational Innovation (ICOI 2019), 100, 663-669. https://doi.org/10.2991/icoi-19.2019.116.

20. Peraturan Menteri Keuangan Nomor 82/PMK.03/2011 tentang Tata Cara Pemeriksaan Pajak.

21. Peraturan Presiden Republik Indonesia Nomor 72 Tahun 2020 tentang Perubahan atas Peraturan Presiden Nomor 54 Tahun 2020 tentang Perubahan Postur dan Rincian Anggaran Pendapatan dan Belanja Negara Tahun Anggaran 2020.

22. Ratmono, D. (2014). Model kepatuhan perpajakan sukarela: peran denda, keadilan prosedural, dan kepercayaan terhadap otoritas pajak (Voluntary tax compliance models: the role of fines, procedural fairness, and trust in tax authorities). Jurnal Akuntansi \& Auditing Indonesia, 18(1), 42-64. https://doi.org/10.20885/jaai.vol18.iss1.art4.

23. Sebele-Mpofu, F. Y. (2020). Governance quality and tax morale and compliance in Zimbabwe's informal sector. Cogent Business and Management, 7(1). https://doi.org/10.1080/23311975.2020.1794662.

24. Setiawan, D., Kurniawan, B., \& Payamta, P. (2018). Dampak penggunaan e-filling terhadap kepatuhan wajib pajak: peran perilaku wajib pajak sebagai variabel mediasi (The impact of using e-filling on taxpayer compliance: the role of taxpayer behavior as a mediating variable). Jurnal Akuntansi \& Auditing Indonesia, 22(1), 12-24. https://doi.org/10.20885/jaai.vol22.iss1.art2. 
25. Shahzad, I., \& Khan, A. A. (2018). Role of Tax Administration System and Public Governance on Taxpayers ' Compliance Behavior , Moderating role of Religiosity. European Online Journal of Natural and Social Sciences, 7(3), 1-18.

26. Sukesi, S., \& Yunaidah, I. (2020). The effect of tax socialization, superior service, and service quality on taxpayers' satisfaction and compliance. Journal of Economics, Business, \& Accountancy $\quad$ Ventura, 347-359. https://doi.org/10.14414/jebav.v22i3.1698.

27. Syakura, M. A., \& Baridwan, Z. (2014). Determinan Perencanaan Pajak dan Perilaku Kepatuhan Wajib Pajak Badan (Determination of Tax Planning and Corporate Taxpayer Compliance Behavior). Jurnal Akuntansi Multiparadigma, 5(2), 170-344.

28. Tahar, A., \& Sandy, W. (2016). Pengaruh persepsi wajib pajak atas pelayanan KPP, sanksi perpajakan dan pengetahuan atas penghasilan kena pajak terhadap kepatuhan wajib pajak (The influence of taxpayer perceptions on the services of the Tax Office, tax sanctions and knowledge of taxable income on taxpayer compliance). Journal of Accounting and Investment. Retrieved from http://journal.umy.ac.id/index.php/ai/article/view/683.

29. Undang-Undang Republik Indonesia Nomor 25 Tahun 2009 tentang Pelayanan Publik

30. Utami, T., \& Susyanti, S. (2018). Economic and Psychological Approach to Increase Tax Compliance in Micro, Small And Medium Enterprises. Jurnal Akuntansi Dan Investasi, 19(1), 54-63. https://doi.org/10.18196/jai.190191.

31. Vythelingum, P., Soondram, H., \& Jugurnath, B. (2017). An assessment of tax morale among Mauritian taxpayers. Journal of Accounting and Taxation, 9(1), 1-10. https://doi.org/10.5897/jat2016.0224. 